\title{
The (mis)management of ethno-linguistic diversity in Ethiopian cities
}

\author{
Zemelak A. Ayele \& Jaap De Visser
}

\begin{abstract}
Ethiopia has an ethnical federal system that is based on the assumption that the ethno-linguistic communities of the country are located in neatly defined, or definable, territorial areas. On the basis of this assumption the federal system aspires to accommodate the ethnic diversity of the Ethiopian people through, principally, if not exclusively, territorial schemes. This assumption is, however, incorrect as far as urban areas are concerned which, despite being territorially enclosed within one of the ethnic-based regions or sub-regional units, have thousands of multi-ethnic dwellers. The territorial scheme thus fails to cater to a large contingent of multi-ethnic urban dwellers.
\end{abstract}

\section{Introduction}

States with population of diverse ethnic or cultural identities use territorial and nonterritorial methods for managing the diversity of their population. The territorial management of diversity, which takes different forms, including federalism or regionalism, presupposes the recognition of a certain territorial area as an autonomous sub-national unit of a particular identity group. This method has been adopted for managing diversity or accommodating minorities in multiethnic and multi-lingual states such as Ethiopia, Switzerland, Canada, Belgium and the like.

The territorial method of managing diversity, however, fails to cater for urban popu- lation, which is often ethnically and linguistically heterogeneous. Cities are built around 'economic logic' rather than cultural affinity or 'political legitimacy through ethnic mem- bership', making them multi-linguistic, multi-ethnic and multi-cultural (Qadeer, 1997). Thus, states that use territorial methods for managing diversity are often faced with the risk of marginalising minorities living in urban areas within ethnically structured sub- national units. This is the case, for instance, in Canada where the recognition of Quebec as the autonomous region of the French-speaking community came at the risk of marginalising the English-speaking community living in cities such as Montreal and Quebec City (Vaillancourt, Coche, Cadieux, \& Ronson, 2012). In Spain, the accommodation of diverse linguistic communities in cities such as Barcelona (the capital of the autonomous regions of Catalonia), Vitoria-Gasteiz (the capital of Basque Country) and Santiago de Compostela (the capital of Galicia) is often at issue. Belgium faces similar challenges in Brussels, the capital of the 
country, which, despite being territorially enclosed within the Dutch- speaking Flemish region, has majority French-speaking and minority Dutch-speaking residents, not to mention the non-European immigrant community (Deschouwer, 2005).

Yet, there is a growing demand for access to urban life, as captured in 'The Right to the City', that guarantees the full usufruct of the city, respecting diversity and preserving the cultural memory and identity of all citizens free of discrimination. 'The right to the city', as initially conceptualised by the French Philosopher Henri Lefebvre, was a call for the 'subordination of the economic function of the city' to its 'social function'. He was concerned about the increasing 'commodification' of urban spaces that undermined the role of the city as a public space and cite of 'social and political life, wealth, knowledge and arts' where differences thrive. Lefebvre thus called for the return of the predominance of the social function of the city, which must allow the participation (enfranchisement) of the ordinary people in how their homes and cities are shaped (Huchzermeyer, 2014). Participation as conceived by Lefebvre is not simply taking part in the framing of urban policies through, for instance, electoral processes or civic engagements. It is rather focused the participation on all decisions and processes that produce urban space (Purcell, 2002).

The concept of 'the right to the city' has now evolved to encompass a wide range of political and socio-economic, cultural and environmental rights, which are recognised in various international instruments and, now, are captured in the 'World Charter on the Right of the Cities'. At the centre of the right to the city, as provided in the Charter, is the recognition of all residents of a city, including those residing in the city provisionally, their ethnic or other identities regardless, as citizens of the city (Art 1 (5)). As citizens, all inhabitants of a city have the 'equitable usufruct' of the city on the basis of 'sustainability, democracy, equity, and social justice' (Art 1(2)). The right to participate of all of the citizens of the city in its political, social and cultural life is thus the corner stone of the right of the city. The participation in the political life includes the right to participate in local elections both as a voter and a candidate based on the principle of equality. Ensuring political 'enfranchisement and social inclusion', and preventing disenfranchisement and social exclusion, are the aspirations proponents of the right to the city hope to achieve. As hinted above, the right to the city is principally based on the recognition of the equal citizenship of all individual residents of the city. It does, however, envisage that certain ethnic or social groups may also be catered for through affirmative actions (Art 2(4)(2)). The cultural aspect of the right to the city requires the preservation of the 'cultural memories and identities' of all citizens of a city (Art 1 (1)).

The right to the city is not a legal right, nor is it part of human rights regimes. However, it is viewed as a 'compelling approach' that embodies legitimate demands for the fulfillment of the essential conditions that are critical for ensuring that individual citizens and social and cultural groups residing in the city have 'dignified and secure existence' (Huch- zermeyer, 2014). 
In this article, it is argued that the institutional and political design of cities in Ethiopia falls short of the standard required to guarantee urban dwellers the full usufruct of the Ethiopian city. In the course of this argument, the paper first identifies the place of cities in Ethiopia's federal arrangement. It then shows how and why cities in Ethiopia have ethnically diverse population. The paper then deals with the issue of whether and how the regional states respond to the ethnic diversity of cities within their jurisdiction in terms of political representation, language and education before offers some final conclusions.

\section{Ethiopia's ethnic federal system and the place of cities in it}

Managing the ethnic diversity of the Ethiopian people is an explicitly stated purpose of the country's federal system. The right to self-determination of every ethnic community of the country being its foundational principle, Ethiopia's federal system is often viewed as a 'federation of ethnic groups' in which the various ethnic communities are 'joined together in a federal union', and, thus, Ethiopia as a state 'founded by and belong[ing] to all ethnic groups' (Gebre-Sellasie, 2003; FDRE Constitution, 1995 Preamble \& Art 39; Herther-Spiro, 2007).

The notion of ethnicity under Ethiopia's federal Constitution is linked to a specific territory based on the supposition that every ethnic community is, or can be, linked to a neatly defined, or definable, territorial area, wherein it is considered an autochthonous community. On the basis of this assumption, Article 39 (5) of the Constitution defines an ethnic community, among other things, by the notion of inhabiting 'an identifiable, predominantly contiguous territory'. Based on the same supposition, the Constitution also uses territorial schemes for accommodating the ethnic diversity of the Ethiopian people (Fiseha, 2007). ${ }^{1}$ Accordingly nine regional states-demarcated largely along ethnic lines-have been established as constituent units of the federation. ${ }^{2}$ Some 25 ethnic local government units, which take the form of either a liyu-woreda (special district) or a nationality zone (special zone), have also been established in five of the nine regions with a view to territorially accommodating intra-regional ethnic minorities 3 (Ayele \& Fessha, 2012).

Within these ethnically structured regional and sub-regional units, there are about 925 urban areas that are categorised as cities or municipalities: more than 820 of the 925 urban settlements are municipalities while the rest are cities (Ministry of Works and Urban Development (MWUD), 2007). The autonomy of the city approximates that of the woreda, the autonomous local government unit established in rural areas. The municipality, on the other hand, serves as an administrative level of the woreda and provides residents with municipal services. In terms of the country's federal system, regulation of and oversight over cities and municipalities is the competence of the ethnic-based regional states and subregional units (Federal Democratic Republic Ethiopia [FDRE] Constitution (1995) Art 50 (4)).

\section{Cities and ethnic diversity in Ethiopia}

As mentioned above, Ethiopia's ethnic-based federal system assumes that the various ethno-linguistic communities of the country are located in distinct territorial 
areas, forming the autochthonous communities of the areas. This assumption is generally accurate as far as the rural areas are concerned which are often ethnically homogenous. 4 It is, however, inaccurate with respect to hundreds of cities and municipalities which have ethnically diverse population.

As Table 1 illustrates, there are millions of urban dwellers living in cities outside the regions or sub-regions where the ethnic communities to which they belong are considered autochthonous.

Table 1. Ethnic composition of the 2 federal cities and 10 cities forming the largest urban settlement in the respective regions

\begin{tabular}{|c|c|c|c|c|}
\hline City & Federal/region & $\begin{array}{l}\text { Autochthonous } \\
\text { ethnic community }\end{array}$ & Population & Ethnic compositions of residents of the city \\
\hline Addis Ababa & Federal & Oromo & 2.37 million & Amhara $(47 \%)$; Oromo $(19 \%)$; Gurage $(16 \%)$; Tigre $(6 \%)$; others $(12 \%)$ \\
\hline Dire Dawa & Federal & Somali & 341,834 & Oromo $(46 \%)$; Amhara (20\%); Somali $(24 \%)$; Gurage $(5 \%)$; others $(5 \%)$ \\
\hline Jigjiga & Somali & Somali & 277,560 & Somali $(99 \%)$; others $(1 \%)$ \\
\hline Hawassa & SNNP & Sidama & 258,808 & $\begin{array}{l}\text { Sidama (48\%); Amhara (15\%); Wolayita (14\%); Oromo (5\%); others } \\
\quad(18 \%)\end{array}$ \\
\hline Mekele & Tigray & Tigrayan & 215,914 & Tigrayan $(96 \%) ;$ Amhara $(2 \%) ;$ others $(2 \%)$ \\
\hline Gonder & Amhara & Amhara & 207,044 & Amhara $(88 \%)$; Tigray $(7 \%)$; others $(5 \%)$ \\
\hline Bahir Dar & Amhara & Amhara & 182,730 & Amhara $(96 \%)$; others $(4 \%)$ \\
\hline Adama (Nazret) & Oromia & Oromo & 155,349 & Oromo $(39 \%)$; Amhara $(35 \%)$; Gurage $(12 \%)$; others $(14 \%)$ \\
\hline Bishoftu (Debre-Zeit) & Oromia & Oromo & 99,928 & Amhara $(43 \%)$; Oromo $(40 \%)$; Gurage $(8 \%)$; other $(9 \%)$ \\
\hline Harer & Hareri & Hareri & 99,368 & Oromo $(56 \%)$; Amhara $(23 \%)$; Hareri $(9 \%)$; Gurage $(4 \%)$; others $(8 \%)$ \\
\hline Gambella & Gambella & Anuak & 39,022 & Anuak $(38 \%)$; Oromo $(26 \%)$; Amhara $(14 \%)$; Nuer $(10 \%)$; others $(12 \%)$ \\
\hline Asossa & $\begin{array}{l}\text { Benishangul- } \\
\text { Gumuz }\end{array}$ & Berta & 24,214 & Oromo $(40 \%)$; Amhara $(30 \%)$; Berta $(20 \%)$; others $(10 \%)$ \\
\hline
\end{tabular}

Source: FDRE: Central Statistics Agency (2007).

Over three million non-Oromo people reside in many cities of the Oromia region. As can be seen in the table, the non-Oromos are in majority in major cities such as Adama and Bishoftu that are found in the Oromia region. The Amharas and Oromos together constitute about 70\% of the residents of Awassa of BenishangulGumuz. Further- more, in Southern Nations Nationalities and Peoples (SNNP) half a million Amharas and quarter of a million of Oromos are found, mostly in the urban areas of the SNNP, in addition to members of other communities. Tens of thousands of Oromos, Amharas and others belonging to various ethnic communities also live in Gambella and Benishangul- Gumuz regions (Population Census Commission, 2008). The cities in northern Ethiopia (the Amhara and Tigray regions) are also ethnically heterogeneous. Gonder, a city located in the Amhara region, has a large number of Tigrayans while Mekele, the capital of Tigray, has a significant number of Amharas. As Table 1 shows, the cities in the southern regions (Oromia, SNNP, Gambella and Benishangul) are much more ethnically diverse than those in the north, since, as explained below, the population movement in Ethiopia, especially in the past one and half century, has been mainly from the north to the south. The ethnic diversity in the Ethiopian cities, especially those in the south, and the political quandaries that it poses, can be explained with reference to historical and economic realities.

The emergence of many of the cities in Ethiopia is linked to the emergence of 'Modern Ethiopia' in the late nineteenth century (Tibebu, 1995). Indeed the five regions of the Abyssinian Empire-the Tigre (in the present day Tigray and Eritrea), Gojjam, Wollo, Gonder (Begemidir) and Showa-had various historical urban settlements, such as Gonder, Axum, Debre Berhan, which, depending on the region controlling 
the central throne, served as seats of the imperial government (Fiseha, 2007).5 There were also several historical cities, such as Harer and Jimma, in the southern half of the country the establishment of which preceded the emergence of 'Modern Ethiopia'. However, the establishment of most of the cities in the southern regions is associated with the territorial expansion of the Abyssinian Empire that brought about 'Modern Ethiopia' (Markakis, 1975; Tibebu, 1995; Zewide, 2002).

Undertaken in the name of nation building, the territorial expansion culminated under Emperor Menilik II (1989 - 1913) in the late 1890s, followed by decades of centralisation under Emperor Haile Sellasie (Zewide, 2002). The territorial expansion was mostly carried out through brute force even though in some cases diplomacy secured Menilik the peaceful submission to his authority of some of the regional and local rulers of southern Ethiopia. This had unfavourable political, economic and cultural consequences for the communities in the areas. In the areas that were militarily overpowered, settlement sites and military garrisons were established for the soldiers, administrators and priests who moved to the areas from northern Ethiopia. Over two-thirds of the lands in these regions were expropriated and re-assigned to the settlers (Tibebu, 1995). Moreover, the Emperor personally appointed regional and local rulers to the areas, often from among his own military leaders, thereby abolishing the traditional authorities and institutions of the southern regions, except where the latter were necessary for exerting control over the local communities (Abbink, 1998). The communities in these regions were encour- aged, if not coerced, to abandon their languages and adopted the language, culture and even religion of the communities of northern Ethiopia (Markakis, 2004).

The garrison towns, which were so established, began to serve as political and admin- istrative centres wherefrom the centrally appointed rulers of the localities exercised control over the communities of the areas. These settlements, eventually, grew to be towns and cities that we know now (Tibebu, 1995). It is, therefore, in such rather infelicitous context that Addis Ababa and most of the cities, in the southern regions, happened to emerge as multi-ethnic urban settlements from the very beginning.

Despite the unhappy context that gave rise to their existence, most of the cities in southern Ethiopia have now become important political and economic centres. Millions of people have moved to these cities from within the southern regions and from the north- ern regions, for reasons that are completely unrelated to the territorial expansion of the old empire, and have accumulated properties, married and inter-married with local residents and established families (Wagaw, 1999). Now most of the urban residents of northern origin who live in the southern regions are second-, third- or even fourth-generation migrants, having little or no connection with the northern regions. Moreover, the urban residents who are autochthonous to the regions have formed a distinct identity as a conse- quence of living in urban areas. Furthermore, there are a large number of urban residents with mixed ethnic origins (Abbink, 1998). 
Economic realities have also contributed to the ethnic diversity of the urban population in Ethiopia. For centuries, individuals belonging to various ethnic communities moved from their homelands to other parts of the country in pursuit of economic interests. Take, for example, the Gurage, Silte and Wolayita, ethnic communities of southern origin. Each has its own nationality zone in the SNNP. However, these nationality zones are overpopulated resulting in members of these communities migrating to urban areas elsewhere in order to engage in business activities (Vaughn, 2003). ${ }^{6}$ The result has been the emergence of large Gurage, Silte and Wolayita communities in cities and municipalities outside of 'their' nationality zones or liyu woredas, both within and outside the SNNP. Thus, as Table 1shows, the Gurages are the third largest community in Adama (Nazret), a city that is located in Oromia. Likewise, the Oromos constitute the second largest community in the city of Gambella, the capital of the Gambella regional state.

The above trend is set to intensify, as Ethiopia becomes an increasingly urbanised country as indicated in Table 1.

Ethiopia is urbanising at the rate of $4 \%$, outstripping the average urbanisation rate of the African continent, which stands at 3.2\% (MoWUD, 2007). This continues to make cities even more ethnically diverse as people of different ethnic origin move from rural to urban areas. The role of cities as hosts of federal and state governments organs such as univer- sities and offices of federal ministries further contributes to the diversification. For example, 21 new universities, in addition to the already existing 11universities, have been established in cities and towns across the country (Addis Fortune, 2015). Indeed the universities are established with the purpose of bringing higher education institutions within geographical proximity of marginalised communities and addressing historic injus- tices (Semela, 2008). Yet, these are federal institutions, governed by federal laws, and which, both in terms of the country's higher education policy and the practice, accept and serve students of all ethnic backgrounds. The instructors and students in the univer- sities are thus by and large from diverse ethnic communities, even though the majority of the academic stuff, especially those in leadership position, are often from the autochthonous communities of the cities or regions where the universities are situated (See Adamu, 2014). These institutions are thus likely to deepen the ethnic diversification of their host cities.

\section{Cities and non-autochthonous communities; political and cultural inclusion}

As mentioned above, the establishment of the Ethiopian federal system is predicated on undoing past political and economic marginalisation of the various ethnic communities of the country, in particular those in the southern regions, principally through territorial methods. Yet the fates of the cities that are enclosed in the ethnic territories have been a cause of incessant debate beginning from the transitional period (1991-1995).

As it is clear from the discussion above, the history that is associated with the emergence of the cities in the southern regions is far from rosy. The very existence of 
the cities is a direct result of the physical and cultural dislocations of the original inhabitants of the areas where the cities are found. The ethnic communities within whose territorial areas the cities are enclosed, therefore, claim historical rights on the lands on which the cities are estab- lished and seek to exercise full political control over the cities. On the other hand there are those who contend that the cities should be organised as autonomous political units outside the jurisdiction of the ethnic-based regional and sub-regional units (Abreham, 1994). They argue that the cities can no longer be "claimed to be "native ethnic areas" of any group except in an anachronistic, nominal sense' (Abbink, 1998). During the drafting of the 1995 Constitution there was heated debate between the proponents of the above two pos- itions. In the end those who were in favour undoing past injustices and allowing ethnic communities full political control over the cities within their territorial areas prevailed.

The exceptions are Addis Ababa and Dire Dawa, the two federal cities. Addis Ababa is the seat of the federal government, with its own government and outside of the jurisdiction of an ethnic regional unit, even if Oromia's 'special interest' in the city, which is yet to be defined, is given constitutional recognition (FDRE Constitution, 1995) Art 491 \& 2). Both the Somali and Oromia regions claim jurisdiction over Dire Dawa-the second largest and cosmopolitan city in Ethiopia. At least for now, this city is an autonomous city under the federal government (FDRE Proclamation No. 416 (2004) Preamble).

The political arrangement that puts ethnically diverse urban areas under ethnically organised regional and sub-regional units has significant political and cultural implications to those residents of the cities not belonging to the dominant ethnic community of the regions or sub-region. The question is whether and how the ethnic territories have balanced the need to correct historical injustices that the respective communities suffered with the right to the cities of urban dwellers not belonging to the autochthonous ethnic communities, in particular, in terms of political representation, language and education.

\section{Political Participation}

There are two reasons why the ethnic federal construct of Ethiopia has important conse- quences for the political representation of individuals of diverse ethnic background resid- ing in a city that is enclosed within an ethnic territory.

First, the establishment of the regional states and the ethnic sub-regional units, within which all the cities, except the two federal cities, are located, is based on the postulate that such arrangement allows a national minority group to become a regional or local majority (Fessha, 2010). The creation of such territorial unit is, therefore, designed and expected to allow the particular group to enjoy a certain degree of political autonomy. This naturally impacts the political fate of 'others' within such a regional or sub-regional unit. Secondly, a regional state has the power to regulate certain aspects of political representation and democratic participation at intraregional level, including, therefore, in the cities within its jurisdiction. The federal electoral law, for instance, allows the regional states to determine the number of seats a city council may have and the number and bound- aries of the electoral 
constituencies for local council elections (Art 29 (2), Proclamation 532/2007). A region can thus use these powers to expand or limit the political represen- tation of urban dwellers of non-autochthonous ethnic background in those cities.

As part of the federal scheme that seeks to address the historical marginalisation, members of the ethnic communities within whose territories the cities are found are expected to gain adequate representation in, and exercise a dominant control over, the pol- itical structures of the cities (Van der Beken, 2014). This is not likely to materialise through the normal electoral process since members of the autochthonous communities are in the minority in many cities of the southern region. This calls for an institutional arrangement that ensures members of such communities are in control of the cities' pol- itical structures. In the absence of such institutional arrangement, the autonomous communities run the risk of being outvoted on major issues concerning the cities. This indeed 'would run contrary to the rationale behind the establishment of ethnic-based territories' (Van der Beken, 2014). Addressing historical issues should not, however, result in the complete disenfranchisement of the urban residents with non-autochthonous ethnic background since this will excessively compromise their right to the city. The question is whether and how the ethnic-based regional states or sub-regional units seek to balance the need to ensure the dominance of the autochthonous communities with responding to the ethnic diversity of the people living in the cities.

The regional states have created various political structures for the cities within their jurisdictions, including city councils and mayoral offices. The southern regions, such as Oromia, SNNP and Benishangul-Gumuz, have also introduced affirmative measures that are meant to address historical marginalisation and enhance the political represen- tation in the cities of members of the autochthonous communities. The northern regions (Amhara and Tigray) have not introduced such a system presumably because the emer- gence of the cities in these regions, unlike those in the southern regions, was not a result of the displacement of the autochthonous communities and that the latter are in majority in all of the cities in these two regions.

The institutional schemes that are so introduced in the southern regions include a quota system that reserves a portion of the seats of the city councils and some or all of the pos- itions in the city executives. In some sense, this arrangement flows from a national law, which expressly provides that a certain percentage of the seats in a local council may be reserved for a local ethnic minority (Proclamation 7/1992). In SNNP, for instance, up to $30 \%$ of the seats in a city council are reserved for members of the autochthonous ethnic communities of the relevant nationality zone or liyu woreda within whose jurisdic- tion the city administration is situated. Rural communities adjacent to the cities may vote to elect representatives into the city council in order to fill the seats that are reserved for the autochthonous ethnic communities (SNNP Proclamation 103/2006 Art 16 (3) (1)). This configuration is applied in particular to cities where members of the autochthonous ethnic communities are in the minority and as long as they remain so. In Oromia up to $50 \%$ of the seats in all city councils are reserved for members of the Oromo ethnic 
com- munity. In addition, 20\% of a city council's seats are reserved for representatives of the rural communities adjacent to the city, which are often predominantly ethnic Oromo. Voters who reside outside the boundaries of the cities are thus allowed to vote in city council elections, arguably to ensure that the Oromos dominate the council (ORS Proclamation 65, 2003 Art 13(3)). Likewise, the City Proclamation of Benishangul- Gumuz regional state also reserves seats for autochthonous ethnic communities: $55 \%$ of a city council in the region is reserved for autochthonous ethnic communities. The regional legislature retains the power to increase this percentage (BGRS Proclamation 69 (2007) Art 10 (5)).

The reservation of political positions for autochthonous communities also extends to the executive branch of the city government. A mayor of a city in SNNP may be elected only from among the members of the city council belonging to the autochthonous ethnic com- munity within whose nationality zone or liyu woreda the city is found (SNNP Proclama- tion 103/2006 Art 21(1) (2)). A city resident with a non-autochthonous ethnic background may thus not be a mayor of a city, no matter how long he or she may have resided in that particular city. Consequently, cities such as Wolkité and Butajira-that are located in Gurage Nationality Zone-can have mayors hailing from only the Gurage community. Likewise only an individual belonging to the Hadiya community can be a mayor of Hosanna, a city located within the Hadiya Nationality Zone. The same applies to the other mono-ethnic nationalities zones.

In Oromia, the mayor and deputy-mayor of a city were elected by the city council from among its members. However, in 2006, this was changed to empower the Regional President to make the appointment of mayors to all cities in the region (ORS Proclamation 116/2006 Art 2 (6)). As the preamble of the amendment law indicates, the change was necessary in order to eliminate all legislative hurdles that limited 'the role of the Oromo people' in the cities. In another words, this must ensure that Oromos occupy all political organs of the cities, including the offices of the mayor and the deputy-mayor.

The requirement proficiency in the working language of a regional state or an ethnic sub-regional unit is the other institutional measure that is meant to enhance the political representation of hitherto marginalised communities. This requirement indeed does not emanate from regional laws but from national legislation, which provides that candidates for elections should be conversant with the working language of the regional state or sub-regional unit and has nationwide application (Proclamation 532/2003 Art 45(1) (b)).

As will be discussed below, each regional state, nationality zone or liyu woreda is authorised to adopt its own working language and cities are generally expected to use the working language of the regional state or the ethnic-based sub-regional unit within whose jurisdiction they are found. It is therefore not sufficient for a candidate who seeks to run for a city council membership to be conversant with the 
working language of the regional government. He or she is also required to command the working language of the relevant city administration.

As it is clear from the above, addressing historical injustice and enhancing the political representation, indeed the political dominance, of members of the autochthonous communities have been given considerable attention in the design of the political structures of the cities in the southern regions. One may argue that in some cases the balance between addressing historical injustice and catering to the ethnic diversity of the residents of the cities has been struck. For instance, in SNNP the reservation of $30 \%$ of the seats in a city council for members of autochthonous communities ensures that the latter are fairly represented. It also leaves $70 \%$ of the seats in the council to be contested for by everyone residing in the cities, including members of the autochthonous communities. Even the reservation of $55 \%$ of the seats of a city council for the autochthonous communities of Benishangul-Gumuz can be viewed as a scheme that ensures that the autochthonous communities have dominant presence in the political structures of the cities without totally excluding residents of the cities of non-autochthonous ethnic background from political representation.

However in some cases, the institutional measures discussed above, coupled with the political practice, go beyond ensuring that the autochthonous ethnic communities dominate the cities' political structures. They rather have the effect of completely excluding those urban dwellers with non-autochthonous ethnic background from any representation in the cities' political structures. For instance Proclamation 65/2003 (Art 13 (3 \& 4)) of the Oromia regional state reserved a maximum of $30 \%$ of the seats in a city council in Oromia for ethnic Oromos and $5 \%$ of the seats for the rural kebeles that are found in the vicinity of a city, an arrangement that could have struck a balance between addressing historical issues and the right to the city of the non-Oromo residents of the cities in Oromia. This was, however, changed when Proclamation 116/2006 was issued that reserved $70 \%$ of the seats in a city council for ethnic Oromos. Now not even a single member of the councils of the cities of Bishoftu and Ambo of Oromia is a non-Oromo (Amensisa, 2012). Moreover, as was mentioned above, the Benishangul-Gumuz regional council retains the power to increase the seats that are reserved for the autochthonous communities of the region. Such an increase, if introduced, will have no other purpose than the exclusion of the non-autochthonous urban dwellers since the reservation of $55 \%$ of the seats in a city council serves the purpose of ensuring the dominance of the autochthonous communities in the cities, let alone their representation.

The constitutionality of the above institutional arrangements is not beyond dispute. Urban dwellers with non-autochthonous ethnic background have certain individual rights that are protected by the FDRE Constitution that the states cannot infringe, even though the former cannot claim group rights, as they do not form a distinct ethnic community (Van der Beken, 2014). The FDRE Constitution (Art 38 (1)) guarantees the right of 'every Ethiopian national', regardless of his or her 'colour, race, nation, nationality, sex, language, religion, political or other opinion or 
other status' to elect and be elected. The right to election 'by universal and equal suffrage' is guaranteed to every Ethiopian in all elections, including local elections. Therefore, elections, including elections for a city council, are held on the basis of this constitutional principle. The national electoral law reiterates the above constitutional principles. It defines the requirements of eligibility for voting and candidacy in any elections, which relate to citizenship, age and duration of residency in a constituency (FDRE Proclamation 532/2007) Art 45). Ethnicity is not among the eligibility requirements either for voting or candidacy in all elections. As a rule, therefore, ethnic background cannot be a requirement of eligibility either to vote or to be a candidate in any elections at any level of government.

Indeed, the Constitution (Art 54 (3)) itself reserves 20 seats in Parliament for what are considered ethnic minorities. It may thus be interpreted to mandate similar arrangements at regional or local level. This provision is, however, aimed at ensuring the representation of minority ethnic communities, which otherwise would be excluded from any political representation. On the other hand, the reservation over $50 \%$ of city council seats has no other purpose than excluding urban residents with non-autochthonous ethnic background making the arrangements constitutionality problematic.

With regard to the language requirement, the FDRE Constitution clearly states that one's right to participate in elections, both as a voter or a candidate, cannot be restricted on the basis of a language requirement. Proficiency in the working language of a regional or local government is, however, found to be constitutional by the House of Federation. 7

\section{Language Right Urban Residents}

As was mentioned above the southward expansion of the Abyssinian Empire had brought about the cultural and linguistic marginalisation of the communities of the southern regions. In particular, with the introduction of Amarigna (Amharic) as the sole official language of the country, members of the communities of the southern regions had no choice but to use the language, or make use of the service of an interpreter, to communicate with local rulers or judges. The linguistic marginalisation of the communities was more pronounced in the urban areas than in the rural areas since the latter served as centres of local and provincial administration (Markakis, 2004; Zewide, 2002).

With a view to addressing the cultural marginalisation of the various ethnic communities of the country, the Constitution provides equal recognition to all languages in the country. It also empowers the ethnic territorial and political units to choose their own working languages (FDRE Constitution, 1995 Art 5 (3)). Amaregna is constitutionally recognised as the working language of the federal government. The language of the dominant ethnic community of the Amhara, Oromia, Tigray and Hareri regional states is used as the official language in those respective regions. The SNNP, Benishangul-Gumuz and Gambella, having no dominant ethnic community, use Amaregna as their working language at regional level. The Afar 
regional state also uses Amaregna as the working language despite Afarigna being recognised in the regional constitution (Art 5) as the official language of the region. In Southern Nations Nationalities and Peoples Region (SNNPR), several mono-ethnic nationality zones, including Sidama, Silte and Hadiya nationality zones, have begun using local languages for official purposes (Cohen, 2000; Smith, 2008). Afaa-Oromo has also become the working language of the Oromo Nationality Zone in the Amhara regional state (Mohammed, 2010). The federal government, the regional states, nationality zones and liyu woredas are monolingual in a sense that they use only a single language for official purposes. The exception is the Hareri regional state, which in its regional constitution (Art 6) has adopted Afaan-Oromo and Hareri as official languages of the region. The issue, therefore, is whether the linguistic diversity of urban dwellers is catered for in a manner that respects the residents' right to the cities.

The federal cities, Dire Dawa and Addis Ababa, have already adopted the working language of the federal government as their official languages. Moreover, as a rule, the working language of a regional state automatically becomes the working language of the cities and municipalities located in it. A city or municipality that is located within a nationality zone or a liyu woreda that has adopted a working language is also expected to adopt that very same working language (Ayele, 2014). Despite its multi-ethnic and multi-lingual population, a city is, therefore, expected to adopt a single working language-except the city of Harer which is found in bilingual region-aligned with the working language of its regional state, nationality zone or liyu woredas. They may not adopt working languages that deviate from the working language of their nationality zones. Afaan-Oromo has thus become the sole working language in several cities in Oromia as is Tigregna in Mekele, the capital of the Tigray region. Several nationality zones in SNNP, including Hadya, Wolyita, Sidama, have opted to use local languages as their working language (Ayele, 2014).

Marginalised communities have, therefore, been culturally empowered since their languages have now official status. The institutional set up does not however cater for those residents of the cities who are not members of the autochthonous communities. The urban dwellers who are not members of the autochthonous communities have no legal right to demand the use of an additional language for official purposes, even at a city level, regardless of the fact that they are found in large number in many cities and municipalities. As Yonatan Fessha $(2010,197)$ states:

[I]ndividuals moving into [other] regions must assimilate. That means Amharicspeaking citizens moving to an Oromifa-speaking region have to leave behind any prior claim to language protection ... this has created a problem in some areas where an important number of minorities are scattered in the midst of the regionally dominant linguistic groups, especially in major urban areas of some of the member states. 
As a result, urban dwellers in Amhara, Tigray, Oromia and Somali regional states and several nationality zones and liyu woredas in SNNP in terms of the law can only communicate with city organs through the official language of the relevant regional or sub-regional unit, which may very well be different from the language they speak. Yet, they have to write their applications or petitions to city administrations in Afaan-Oromo and Somali languages, respectively. Residents of the cities in Oromia who cannot write and read Afaan-Oromo are required to have their applications or petitions translated into Afaan-Oromo. The same applies to urban residents in several nationality zones and liyu woredas in the SNNP that have opted to use local languages for official purposes. In all cities in Oromia and Somali regional states identity cards, driving licenses, traffic tickets, birth and death certificates, and marriage certificates are issued in Afaan-Oromo and Somali languages, respectively. The same obtains in several cities of the SNNPR that are located in nationality zones that use local languages as own working language.

A further consequence of the adoption of the 'regional' language as official language is that it is has become near impossible for non-autochthonous urban residents to find employment in the civil service organs of cities and municipalities. The working language of these organs is the first barrier encountered by urban residents of nonautochthonous ethnic background who do not speak the local language when looking for jobs in the cities and municipalities. City administrations in Oromia use AfaanOromo as the sole working language. City residents, who cannot speak, read and write Afaan-Oromo, are automatically disqualified from employment in the city administrations and municipalities. As a result, those with non-autochthonous ethnic background who worked as teachers or as employee of government officials were fired (Teshome, 1999). Graduates of the universities and colleges in these cities, who do not belong to autochthonous communities, have little hope of finding employment there. Therefore they have no choice but to migrate to Addis Ababa or other regions in search of employment. The non-autochthonous residents of cities and municipalities of the SNNPR located in nationality zones or liyu woredas that use local languages for official purpose face similar problems. ${ }^{8}$

The same can also be said with respect to the two federals cities, Addis Ababa and Dire Dawa, since the federal government has legally adopted Amaregna as the only working language of these cities. This is despite the fact that Dire Dawa has a significant number of Somali and Oromo residents and that Addis Ababa serves as the capital of the Oromia regional state. For instance, the ethnic Somalis in Dire Dawa, 24\% of the total number of residents of the city, make up a mere $5 \%$ of all of the civil servants of the city. Yet the Amharas, 20\%of the city's entire residents, represent 45\%of the city's civil servant (Midega, 2014). The overrepresentation of the Amharas and the under representation of the Somalis in the city's civil service are due to the language policy of the federal government that provides Amaregna the privilege of being the only working language of the city (Midega, 2014).

It is important to note that one has no choice but to tolerate some of the unfavourable consequences of the language policies described above with relation to the regional cities if historically marginalised communities are to be, and feel, 
culturally empowered. Moreover, the non-autochthonous residents of the cities are from diverse ethnic communities. It is thus practically impossible for the cities to cater to every urban dweller through their language policies even if they had the political will and the necessary legal power to adopt additional working language/s. It is often suggested that Amaregna, being the language that is widely spoken among urban dwellers, can be used as an additional working language in the cities. Such a suggestion is, however, often seen as unacceptable because, given the privileged status that Amharic enjoyed in the past, an arrangement of this sort would certainly put a hindrance against the development of hitherto marginalised languages (Fessha, 2010).

In any case practice shows that the cities are much more accommodative in that many cities in the southern regions use Amaregna for some purposes besides the working languages of the regional states, nationality zones or liyu woredas within which they are found. For instance, it is common to see street signs in many cities of Oromia that are written in two, and often, three languages: Afaan-Oromo, Amaregna and English. In Adama, Bishoftu, Jimma, etc., government offices, business centres and shops put signs that are written in Afaan-Oromo, Amaregna and some times, English. Moreover, some of the official documents issued by the cities in Oromia are prepared in Afaan-Oromo and Amaregna. For instance, the receipt that is prepared by the Oromia Finance and Economic Development Bureau, which is also used by the city governments in Oromia regional state for collecting taxes and other revenues, is prepared both in Afaan-Oromo and Amaregna. In Benishangul-Gumuz and Gambella, Amaregna is still retained as the working language of the regional government. The nationality zones and liyu woredas in these regions have not begun using local languages for official purpose even if constitutionally they are entitled to do so. Hence the cities in these regions use Amaregna for official purposes (Ayele, 2014).

\section{Education in Cities}

Determining which language or languages are used for education is also a matter that is often left to the ethnic-based sub-stat units. In some cases the education competence also includes the power to formulate the educational curriculum in the sub-state unit. Control over education matters is left to ethnic territorial units because education is a 'central vehicle of cultural transmission' (Smith, 2008).

As was briefly mentioned above, ethnic communities of the southern regions were compelled to abandon their languages and receive education in the Amaregna language, an aspect of cultural marginalisation that they historically experienced. The federal dispensation seeks to remedy this historic marginalisation. To this effect, the FDRE Constitution recognises the right of each ethnic community 'to speak, write and develop its language' and to receive education in its own language (FDRE Constitution, 1995 Art 39 (2)).9 Moreover, it is the policy of the federal government to ensure that primary education is offered to each ethnic community either in its own language or in the language that the ethnic community chooses. Amaregna is simply given as a subject in primary schools of various nationality zones only 
because it is considered 'a language of countrywide communication' (Ministry of Education, 1994).

A regional state, a nationality zone or a liyu woreda has the authority to pass a policy decision on the language that is to be used in primary schools, while a cities and woredas are responsible for building school and hiring teachers (Garcia \& Rajkumar, 2008). It is, however, unclear whether students with non-autochthonous ethnic background in the cities and municipalities have the right to receive education in their own language. The Gambella Constitution (2002, Art 6 (4)), after recognising the right of the ethnic communities of the region to learn in their own language, provides that the 'people in the region have the right to learn in [Amaregna ]'. The term 'the people in the region' seems to refer to those not belonging to one of the five autochthonous ethnic communities of the region. Thus, in this region Amaregna is designated as the medium of education in which all students of non-autochthonous ethnic background may legally demand to be educated. Hence, cities and municipalities in this region seem to be enjoined by the regional constitution to use Amaregna for providing primary education to students with non-autochthonous ethnic background. It should be noted that Amaregna is designated as the only language of education for all students of non-autochthonous ethnic background in the region. Hence, for instance, the Oromos in the Gambella City may not, in terms of the regional constitution, demand for the establishment of public-funded primary schools that provide primary education in Afaan-Oromo nor may the Tigrayans demand a school or a classroom that offers education in Tigregna.

None of the other regional constitutions deal with the question of whether students of non-autochthonous ethnic background are entitled to receive education in a language other than the language of the autochthonous community. Thus, it is unclear whether the city governments and municipal administrations are compelled to offer mother-tongue education to students of non-autochthonous ethnic background within their jurisdictions.

The FDRE Constitution provides that ' $[t]$ he State has the obligation to allocate ever increasing resources to provide to the public health, education and other social services'. It further adds that '[e]very Ethiopian national has the right to equal access to publicly funded social services'. The obligation to ensure access to governmentfunded service does not exist with reference to communities but with reference to 'every Ethiopian'. Based on these constitutional principles, one may argue that cities and municipalities, as components of the state, are obliged to ensure mother-tongue education for all residing within their territorial jurisdiction. The schools that are run by cities and municipalities are funded by the state. Hence, students of nonautochthonous ethnic background may demand equal access to these state-funded schools. Equal access should be read to imply the right to be educated in one's own language (Ayele, 2014).

Another argument is also possible. One may argue equal access to a state-funded education does not necessarily imply the right to be educated in one's own language. It simply implies a right to be enrolled in the existing schools, regardless of the language 
the schools use to provide primary education. Students of non-autochthonous ethnic background thus have no right to a mother-tongue education, since the FDRE Constitution does not enjoin the regional states to accommodate them with mother-tongue education. It may then follow that cities are not required to provide mother-tongue education to students of non-autochthonous ethnic background.

In any case, it is clear that those with non-autochthonous ethnic background lack a firm legal basis to demand education in a language other than that of the dominant ethnic community of the particular regional or sub-regional unit. Indeed one cannot expect every city to provide mother-tongue education to all of its residents. The cities do not have the necessary resources and manpower to do so. Even more doing so is simply impractical having in mind ethnic diversity urban dwellers. However, it is encouraging to note that several cities in the southern regions are accommodating students with non-autochthonous ethnic background with education in Amaregna. A number of cities in Oromia regional state have established separate schools or separate classes in Amaregna for non-Oromo communities (Smith, 2008). For instance in Bishoftu, all of the 14 public schools have separate classes for providing education in Amaregna. There are also more than 32 private schools providing education in Amaregna for students from the non-Oromo communities (Amensisa, 2012). Similarly, there are two public schools and two other private schools in Ambo providing education in both Afaan-Oromo and Amaregna (Amensisa, 2012). Similar trend is seen in the SNNPR where schools in the capitals of nationality zones and liyu woredas use Amaregna as the language of instruction for primary education (Smith 2008, 226). In the capitals of monoethnic nationality zones Amaregna is used for education along with the language of the dominant ethnic community of the nationality zone.

Amaregna is, for instance, used alongside sidamigna in primary schools of Hawassa city administration that is the capital of Sidama nationality zone as well as of the SNNPR. It is also used alongside gamogna in Arba-Minch, the capital of Gamo-Gofa Nationality Zone. In Sodo, the capital of Wolayita nationality zone, Amaregna and wolayitegna are used in primary schools. In Hossana, the capital of Hadiya nationality zone Amaregna is used along with hadiyisa while in Dilla, the capital of Gedeo nationality zone, gedeofaa is used for the same purpose. In Bench-Maji zone and South Omo nationality zones have opted to use Amaregna for education in primary schools. Moreover, the Gurage nationality zone and the Alaba liyu woreda in SNNPR have opted to using Amaregna for school and official purposes (Cohen, 2000; Fessha, 2010). In these nationality zones, students of non-autochthonous ethnic background can receive education in Amaregna.

\section{Conclusion}

For historical reasons, most cities in Ethiopia, especially those in the southern regions, have multi-ethnic and multi-lingual urban residents. The manner in which the communities in the cities are organised had thus less to do with ethnic affinity than with economic logic. However, with the introduction of the country's ethnic federalism in 1995, the cities, with the exception of two federal cities, have become 
enclosed within, and become the competences of, ethnically organised regional and sub-regional territorial and political units.

The Ethiopian ethnic federal system follows the rule of territoriality on matters of political representation, language and education, with little or no institutional mechanism for accommodation of urban residents not belonging to the dominant ethnic community of the relevant regional or sub-regional units. Thus, there are no special schemes to ensure the political representation of non-autochthonous communities in the Ethiopian cities and municipalities. On the contrary, the ethnically organised regions within which the cities fall have introduced legal measures that have the effect of systematically limiting the democratic participation of non-autochthonous communities. The cities also have no legal duty to accommodate the linguistic diversity of their residents. Hence urban residents not belonging to the dominant ethnic communities of the regional and sub-regional units have no legal right to receive public services and education in their own languages.

In practice cities seem to take into consideration the ethnic diversity of their residents in the manner they provide services, despite lacking explicit institutional arrangement to this effect. Many cities are in practice bi-lingual in a sense that they use the language of the dominant ethnic community of the regional or the subregional unit along with Amaregna for some purposes, even though legally only the former is recognised as the working language. The cities also establish separate schools or separate classes for the purpose of providing primary education.

It is suggested that the excessive limitations on the political representation of urban dwellers of non-autochthonous ethnic background need to be reconsidered. Such limitations, needless to say, are against their right to the cities and contrary to the constitutional stipulations that guarantee everyone's right to elect and be elected, regardless of one's ethnic identity. Indeed affirmative measures are needed to empower those communities who were marginalised as the direct result of the establishment of many of the urban settlements. This can be achieved, for instance, through the reservation of a maximum of $50 \%$ of the seats in a city council for the autochthonous communities. Exceeding this serves no purpose but the complete and unconstitutional exclusion of those with non-autochthonous ethnic background.

\section{Acknowledgements}

The authors wish to express their gratitude to the Institute of Federalism, University Fribourg (Switzerland), Charles Stewart Mott Foundation and the National Research Foundation for their financial assistance.

\section{Notes}

1. The Constitution provides that the right to self-determination of each ethnic community finds expression in the ability of the community to exercise selfgovernance over the territory it inhabits (FDRE Constitution, 1995 Art 39 (3)). It further provides that the boundaries of the constituent units of the federation are 
demarcated 'on the basis of the settlement patterns, language, identity and consent of the people' (FDRE Constitution, 1995 Art 46 (2)).

2. The regional states are Afar, Amhara, Beinshangul-Gumuz, Gambella, Hareri, Oromia, Southern Nations, Nationalities and Peoples' Region, Somali and Tigray. FDRE Constitution (1995) 47 (1).

3. These regions are Afar, Southern Nations, Nationalities and Peoples Region (SNNPR), Benishangul-Gumuz, Gambella and Amhara regions.

4. There are 63 ethnic communities that are territorially concentrated ethnic communities in Ethiopia. See Negarit Gazeta of the Ethiopian Transitional Government: A Proclamation to provide for the establishment of national regional self-governments (No. 7 1992).

5. The seat of the central throne moved from one region to the other depending on the regional ruler who asserted power. For instance, Gonder was the seat of the throne until power shifted to Showa when Emperor Menilik II ascended to the throne. What is remarkable is that the provincial ruler sought to control the centre; hardly ever did they seek to break away from it.

6. It should also be noted here that a resident of a city who is autochthonous to a particular region may be considered as a migrant and treated as such if he or she is nonautochthonous to the sub-regional unit within which the city is found. For instance, one can consider a Sidama resident of the town of Sodo, the capital of the Wolaita nationality zone, as migrant despite the fact that he or she is considered as an autochthonous resident of the region. The same can be said to a Wolayita who lives in Hosana, the capital of Hadiya nationality zone.

7. The constitutionality of the language requirement was at issue during the 2000 national and regional elections. Some candidates were disqualified from running for election since they did not speak any of the languages autochthonous communities the Benishangul-Gumuz regional states. The working language of the region was, however, Amaregna, which the individuals were conversant. The matter was taken to the House of Federation, the second chamber of the national parliament, which under the FDRE Constitution is empowered to resolve constitutional disputes (see FDRE Constitution (1995) Art 62 (1)). The HoF decided that while the requirement of being conversant in local language is unconstitutional, the requirement of being conversant in working language of a regional states or sub-regional unit was constitutional.

8. Moreover, it is often alleged those with non-autochthonous ethnic background are discriminated against even if they have the necessary language proficiency, 'simply because they belong to ethnic groups other than those predominant in the region' or subregional unit (Teshome, 1999). They are discriminated against even in the cities that have not adopted local languages as their working language (Berhanu, 2007).

9. The Gambella Constitution, for instance, expressly provides that each of the ethnic communities of the region has the right to learn in their own language. Likewise, the Benishangul-Gumuz regional Constitution recognises the right of the ethnic communities of the region to receive education either in their own language or in the language of their choice. Gambela Regional State Constitution (2002) Art 6 (3); Benishangul-Gumuz Regional Constitution (2002) 6 (3). 


\section{References}

Abbink, J. (1998). New configurations of Ethiopian ethnicity: The challenge of the South. Northeast Africa Studies, 5(1), 59-81.

Abreham, K. (1994). Ethiopia from bullets to the ballot box: The bumpy road to democracy and the political economy of transformation. Lawrenceville, Georgia: The Red Sea Press.

Adamu, A. (2014). Ethnic and religious diversity in higher education in Ethiopia: The case of Bahir Dar (Unpublished Dissertation University of Tampere: School of Education).

Addis Fortune. (2015). Better for tertiary education policy to focus on quality. Retrieved from http://addisfortune. net/columns/better-for-tertiaryeducation-policy-to-focus-on-quality/.

Amensisa, T. (2012). Accommodation of minority rights in the Oromia National Regional State City Administrations: The cases of Ambo and Bishoftu. Addis Ababa: Civil Service University, Unpublished MA Thesis.

Ayele, Z. (2014). Local Government in Ethiopia: Advancing development and accommodating ethnic minorities. Baden-Baden: Nomos Verlagsgesellschaft.

Ayele, Z., \& Fessha, Y. (2012). The constitutional status of local government in federal systems: The Case of Ethiopia. Africa Today, 58(4), 89-109.

Cohen, G. (2000). Language and ethnic boundaries: Perceptions of identity expressed through attitudes towards the use of language education in Southern Ethiopia. Northeast African Studies, 7(3), 189-206.

Deschouwer, K. (2005). Kingdom of Belgium. In J. Kincaid \& A. Tarr (Eds.), Constitutional origins, structures, and change in federal Countries: A global dialogue on federalism (pp. 48-75). London: McGill-Queen's University Press.

FDRE Constitution. (1995). Negarit Gazeta of the Federal Democratic Republic of Ethiopia Proclamation of the Constitution of the Federal Democratic Republic of Ethiopia No 1/1995.

Federal Democratic Republic Ethiopia. (1994). Ministry of education, education and training policy. Addis Ababa.

Federal Democratic Republic of Ethiopia (FDRE), Ministry of Works and Urban Development (MWUD). (2007). Plan for accelerated and sustained development to end poverty (2005/o6 - 2009/10): Plan for urban development and urban good governance. Addis Ababa.

Federal Democratic Republic of Ethiopia (FDRE). (2008). Population Census Commission (PCC). Summary and Statistical Report of the 2007 Population and Housing Census Results (2008).

Fessha, Y. (2010). Ethnic diversity and federalism: Constitution making in South Africa and Ethiopia. Farnham: Ashgate.

Fiseha, A. (2007). Federalism and the accommodation of diversity in Ethiopia: A comparative study. Nijmegen: Wolf Legal Publishers.

Garcia, M., \& Rajkumar, A. (2008). Achieving better service delivery through decentralization in Ethiopia. Washington, DC: World Bank.

Gebre-Sellasie, A. (2003). Ethnic federalism: Its promise and pitfalls for Africa. Yale Journal of International Law, 28, 51-107. 
Herther-Spiro, N. B. (2007). Can ethnic federalism prevent "recourse to rebellion?" - A comparative analysis of Ethiopian and Iraqi constitutional structures. Emory International Law Review, 21, 321-372.

Huchzermeyer, M. (2014). Forced evictions and 'the right to the city'. In T. van Lindert \& D. Lettinga (Eds.), Changing perspectives on human rights: The future of human rights in an Urban World; exploring oppor- tunities, threats and challenges (pp. 29-34). Amnesty International Netherlands.

Markakis, J. (1975). Ethiopia: Anatomy of a traditional polity. Addis Ababa: Shama Books.

Markakis, J. (2004). Conflict in prefederal Ethiopia. First national conference on federalism, conflict and peace building. Addis Ababa: Ministry of Federal Affairs, pp. $11-24$.

Midega, M. (2014). Dire Dawa under coalition rule: Ethiopian regional ethnic politics or federal geopolitics. Ethiopian Journal of Federal Studies, 1(2), 95 114.

Mohammed, A. (2010). The use of mother-tongue in education: The case of AfaanOromo in Oromo Nationality Zone of Amhara National Regional State. In A. Habtu (Ed.), Ethiopian federalism principle, process and practice (pp. 140 161). Addis Ababa: Fifth International Conference on Federalism Secretariat.

Purcell, M. (2002). Excavating Lefebvre: The right to the city and its urban politics of the inhabitant. GeoJournal, 58, 99-108.

Qadeer, M. (1997). Pluralistic planning for multicultural Cities: The Canadian practice. Journal of the American Planning Association, 63(4), 481-494.

Semela, T. (2008). Breakneck expansion and quality assurance in Ethiopian higher education: Ideological rationales and economic impediments. Higher Education Policy, 24, 399-425.

Smith, L. (2008). The politics of contemporary language policy in Ethiopia. Journal of Developing Societies, 24(3), 207-243.

Tibebu, T. (1995). The making of modern Ethiopia 1896 - 1974. Lawrenceville: The Red Sea Press.

Vaillancourt, F., Coche, O., Cadieux, M., \& Ronson, J. L. (2012). Studies in language policy: Official language policies of the Canadian Provinces: Costs and Benefits in 2006. Fraser Institute.

Van der Beken, C. (2014). Federalism, local Government and minority protection in Ethiopia: Opportunities and challenges. Journal of African Law, 59(1), 1- 28.

Vaughn, S. (2003). Ethnicity and power in Ethiopia. Unpublished PhD thesis, The University of Edinburgh.

Wagaw, T. (1999). Conflict of ethnic identity and the language of education policy in contemporary Ethiopia. Northeast African Studies, 6(86), 75-88.

Zewide, B. (2002). A history of modern Ethiopia 1855 - 1991. Addis Ababa: Addis Ababa University Press. 


\section{Constitutions and Statutes}

Debub Negarit Gazeta of Southern Nations Nationalities and peoples Regional State (SNNPR): The revised cities proclamation: Proclamation No. 103 (2006).

Federal Negarit Gazeta of the Federal Democratic Republic Ethiopia: Dire Dawa Government Charter Proclamation No. 416 (2004).

Negarit Gazette of the Federal Democratic Republic of Ethiopia: The amended electoral law of Ethiopia: Proclamation No. 532 (2003).

Gambela Regional State Constitution (2002) Art 6 (3); Benishangul-Gumuz Regional Constitution (2002) 6 (3).

Hareri People's Regional Constitution (2004).

Lisane Hig Gazeta of the Benishangul-Gumuz Regional State, A proclamation to provide for the establishment and organisation of urban centres of the Benishangul-Gumuz Regional State and definition of their powers and duties 69 (2007).

Oromia, M. Regulation issued to implement Oromia urban administration proclamation 65 (2003) Proclamation No. 53 (2005).

Negarit Gazeta of the Ethiopian Transitional Government: A Proclamation to provide for the establishment of national regional self-governments (No. 7 1992).

Negarit Gazette of the Afar Regional State: A proclamation to establish and define powers and functions of Semera City Administration 33 (2006).

The Constitution of the Federal Democratic Republic of Ethiopia (1995).

The Revised Constitution of the Afar National Regional State (2001).

World Charter on the Right to the City (2004). 